\title{
OCHRATOXIN A IN BRAZILIAN GREEN COFFEE ${ }^{1}$
}

\author{
Luís A.B. LEONI², Regina P.Z. FURLANI², \\ Lucia M. VALENTE SOARES ${ }^{2},{ }^{*}$, Paulo Lauro C. OLIVEIRA ${ }^{3}$
}

\begin{abstract}
SUMMARY
Ochratoxin A is a nephrotoxic, teratogenic and imunotoxic compound produced by Aspergillus and Penicillium spp. It is a suspected carcinogen to humans and it is carcinogenic to rats. Recently it has drawn attention because it has been found in coffee and it has been the object of regulation by coffee importing countries. Brazil is the largest coffee producing country and its largest consumer. In order to conduct an initial assessment of the situation of the coffee produced in the country and offered to its population, one hundred and thirty two samples of Brazilian green coffee from 5 producing states (Minas Gerais, Paraná, São Paulo, Espírito Santo and Bahia) and destined for the home market, were collected at sales points at the cities of Londrina and Santos, Brazil, and analyzed for ochratoxin A. The toxin was isolated in immunoaffinity columns and quantified by HPLC with florescence detection. The limit of detection was $0.7 \mathrm{ng} / \mathrm{g}$ and the average RSD for duplicates of the samples was $11 \%$. Twenty seven samples were found contaminated with the toxin and the average concentration for the contaminated samples was $7.1 \mathrm{ng} / \mathrm{g}$ ochratoxin A. Neither the total number of defects nor the number of specific defects according to the Brazilian coffee classification system (black, partly - black, sour, stinkers-black, stinkers-green, pod beans) showed any relation to the contamination of the samples with ochratoxin A.
\end{abstract}

Keywords: Mycotoxins; ochratoxin A; Brazilian coffee.

\section{RESUMO}

OCRATOXINA A EM CAFÉ VERDE BRASILEIRO. Ocratoxina $A$ é um composto nefrotóxico, teratogênico e imunotóxico produzido por espécies de Aspergillus e Penicillium. Foi demonstrado ser carcinogênico para ratos e é possivelmente carcinogênico para humanos. Recentemente a toxina despertou atenção por ter sido encontrada em café e ter sido objeto de regulamentação por países importadores. O Brasil é o maior produtor de café no mundo e também seu maior consumidor. Para conduzir uma avaliação inicial da situação do café produzido no país e oferecido à sua população, cento e trinta e duas amostras de café verde brasileiro, provenientes de 5 Estados produtores (Minas Gerais, Paraná, São Paulo, Espírito Santo, e Bahia) e destinadas ao mercado nacional, foram coletadas em pontos de comercialização nas cidades de Londrina e Santos, Brasil, e analisadas para ocratoxina A. A toxina foi isolada em colunas de imunoafinidade e quantificada em cromatógrafo líquido de alta eficiência com detector de fluorescência. O limite de detecção foi $0,7 \mathrm{ng} / \mathrm{g}$ e o coeficiente de variação médio entre duplicatas foi $11 \%$. Vinte e sete amostras estavam contaminadas com a

\footnotetext{
${ }^{1}$ Recebido para publicação em 17/11/00. Aceito para publicação em 12/04/01.

2 Faculdade de Engenharia de Alimentos, Universidade Estadual de Campinas, Caixa Postal 6121, CEP 13081-970 Campinas, S.P. e-mail: valente@fea.unicamp.br

${ }^{3}$ Consultor em processamento e comercialização de café, Rua Pistóia 15, CEP 860202-450, Londrina, PR.

${ }^{*}$ A quem a correspondência deve ser enviada.
}

toxina e a concentração média para as amostras contaminadas foi $7,1 \mathrm{ng} / \mathrm{g}$ de ocratoxina $A$. Nem o número total de defeitos e nem o número de cada defeito específico encontrado na classificação das amostras de acordo com o sistema brasileiro de classificação (preto, meio-preto, ardido, verde-preto, verdes, brocados, coco) mostrou ter qualquer relação com a contaminação presente nas amostras.

Palavras-chave: Micotoxinas, ocratoxina A, café brasileiro.

\section{1 - INTRODUCTION}

Ochratoxin $A$ is a toxic metabolite produced by Aspergillus and Penicillium spp. Among those A. ochraceus is pointed out as a main producer. Ochratoxin $A$ is acutely toxic to all animals tested so far and this includes birds, mammals and fishes. It has also shown teratogenic and immunotoxic properties [2]. The kidneys are its main target organ. It is a potent carcinogenic agent to rats [19] and possibly carcinogenic to humans [8]. It has been suggested as the causative agent of the endemic human nephropathy affecting humans in the Balkans [14]. Nephropathies reported in Algeria and Tunisia have been correlated with the presence of the toxin in bodily fluids and in the food consumed by the population [4]. The natural occurrence of ochratoxin A in green coffee beans has been reported by several authors in concentrations ranging between 0.2 and $360 \mathrm{ng} / \mathrm{g}[3,10,11$, $12,13,16,17,18]$.

Recently ochratoxin A has drawn attention because it has been found in coffee and it has been the object of regulation by coffee importing countries $[6,20]$. Brazil is the largest coffee producing country and its largest consumer. In order to conduct an initial assessment of the situation of the coffee produced in the country and offered to its population, the present work examined samples of Brazilian green coffee from 5 producing states and destined for the home market collected at sales points in the cities of Londrina and Santos, Brazil. The incidence of ochratoxin $A$ and the total number of defects or the number of specific defects (black, partly - black, sour, stinkers-black, stinkers-green, pod beans) were also examined for possible correlation.

\section{2 - MATERIALS AND METHODS}

\section{1 - Sampling}

One hundred and thirty two samples of Brazilian green coffee from 5 producing states (Table 1) and destined for the home market were collected at sales points in the cities of Londrina and Santos, Brazil. The samples were classified by the number of specific defects 
(black, partly - black, sour, stinkers-black, stinkers-green, pod beans) according to the official Brazilian coffee characterization system [15]. About $300 \mathrm{~g}$ of coffee grains were taken to the lab and dried for 16 hours at $50^{\circ} \mathrm{C}$ and then ground to 40 mesh and kept in polyethylene flasks until analysis.

TABLE 1. Green coffee sample distribution according to state of origin in Brazil

\begin{tabular}{lc}
\hline State & Number of samples \\
\hline Minas Gerais & 35 \\
Paraná & 65 \\
São Paulo & 13 \\
Espirito Santo & 17 \\
Bahia & 2 \\
\hline
\end{tabular}

\section{2 - Ochratoxin A determination}

The samples were extracted and submitted to cleanup as previously described by FURLANI \& VALENTE SOARES [5] as follows: Ten grams of sample were extracted with $200 \mathrm{~mL} 1 \% \mathrm{NaHCO}_{3}$ during 3 minutes in a blender at low speed. The extract was then filtered through a glass filter (Whatman GFB, USA) and an aliquot of $20 \mathrm{~mL}$ was taken and added to $20 \mathrm{~mL}$ phosphate saline buffer (Sigma, USA). The resulting solution was applied to an immunoaffinity column (Ochraprep, RhôneDiagnostics, UK). The column was washed with $20 \mathrm{~mL}$ water and after that dry air was passed through the column. The toxin was eluted from the column with $1.5 \mathrm{~mL}$ methanol: acetic acid $(98+2)$ followed by $1.5 \mathrm{~mL}$ water $(0.5 \mathrm{~mL} / \mathrm{min})$. The eluate was evaporated to dryness and dissolved with $1 \mathrm{~mL}$ methanol: acetic acid $(65+35)$. The immunoaffinity columns were used up to 3 times. After the first use the columns were reconditioned according to ZIMMERLI \& DICK [21] and kept at $6-8^{\circ} \mathrm{C}$ until needed.

The extract eluted from the immunoaffinity column was injected into a high performance liquid chromatograph comprising: Waters pump, model 510; Rheodyne injector with $100 \mathrm{~mL}$ loop; Hewlett Packard fluorescence detector, model 1046A; Waters integrator, model 740; Spherisob ODS- 2 column, $5 \mathrm{~mm}, 250 \times 4.6 \mathrm{~mm}$. The mobile phase was methanol: $9 \%$ acetic acid $(65: 35)$ at $1.0 \mathrm{~mL} / \mathrm{mim}$. The excitation and the emission wavelengths were $330 \mathrm{~nm}$ and 470nm, respectively. Quantification was achieved by external standard. The Ochratoxin A standard was obtained from Sigma (USA). The standard solutions were prepared and calibrated according to AOAC INTERNATIONAL [1].

The analytical quality control included a recovery test in each series of samples analyzed. All immunoaffinity columns in the series were either new or were used the same number of times. The duplicates were analyzed on different days and the results were corrected for the recovery of the series.

\section{3 - RESULTS AND DISCUSSION}

Twenty seven samples were found contaminated with the toxin and the average concentration for the contaminated samples was $7.1 \mathrm{ng} / \mathrm{g}$ ochratoxin A (Table 2). The limit of detection for ochratoxin A was $0.7 \mathrm{ng} / \mathrm{g}$ ochratoxin A and the average RSD for duplicates of the samples was $11 \%$. The multiple use of immunoaffinity columns resulted in acceptable recoveries for trace analysis at ppb level as well as the RSD for the duplicate results of the samples [7]. The results also showed that the specific brand of immunoaffinity columns used in the present work could be used for up to 3 times with green coffee samples (Table 3). A greater number of uses per column was not tried as they tend to clog after 3 uses with coffee samples. It should be noted that coffee is a specially hard sample to cleanup due to the presence of a great number of interfering compounds. On the other hand, the repeated use of the immunoaffinity columns during the cleanup step significantly lowered the costs of the analyses.

TABLE 2. Ochratoxin A in Brazilian green coffee

\begin{tabular}{|c|c|c|c|}
\hline \multicolumn{2}{|c|}{ Samples } & \multicolumn{2}{|c|}{ Ochratoxin A $(\mathrm{ng} / \mathrm{g})$ in contaminated samples } \\
\hline Total & Contaminated & Range & Average \\
\hline 132 & 27 & $0.7-47.8$ & 7.1 \\
\hline
\end{tabular}

TABLE 3. Ochratoxin A recovery results for new and reused immunoaffinity columns

\begin{tabular}{lccc}
\hline Level of use & Number of tests & Average recovery (\%) & Recovery range (\%) \\
\hline $1^{\text {st }}$ use & 9 & 80.4 & $69.7-94.4$ \\
$2^{\text {nd }}$ use & 9 & 80.7 & $77.6-85.2$ \\
$3^{\text {rd }}$ use & 2 & 80.3 & $77.3-83.3$ \\
\hline
\end{tabular}

The results of the present survey indicate that ochratoxin A contamination has low incidence and levels in Brazilian coffee when compared with data for coffee from other countries $[6,20]$. Of course, the ideal situation is the absence of such a contaminant in the commodity and research should be undertaken in order to pinpoint the critical steps in which the toxin is produced by the fungi as well as the ways to avoid such a contamination. A similar situation has been reported in the case of roast and ground coffees and of instant coffees offered to consumers within the country as the ochratoxin A levels found for were low [9].

TABLE 4. Defects (\%) in the 130 green coffee samples analyzed for ochratoxin $\mathrm{A}$.

\begin{tabular}{lll}
\hline Range Average & & \\
\hline Black & $0-12$ & 0.58 \\
Partly-black & $0-1.40$ & 0.26 \\
Sour & $0-12.3$ & 2.18 \\
Stinkers-black & $0-3.90$ & 0.41 \\
Stinckers-green & $0-24.0$ & 4.6 \\
Pod beans & $0-1.0$ & 0.05 \\
Total & $0-29.0$ & 8.4 \\
\hline
\end{tabular}


Neither the total number of defects nor the number of specific defects classified according to the Brazilian coffee classification system (black, partly - black, sour, stinkers-black, stinkers-green, pod beans) (Table 4) showed any relation to the contamination of the samples with ochratoxin A.

\section{4 - REFERENCES}

[1] AOAC INTERNATIONAL, 1997. Official Methods of Analysis of the AOAC International. $16^{\text {th }}$ edition, AOAC International, Gaithersburg, Chapter 49, pp.1-51.

[2] BUSBY JR., W.F.; WOGAN, G.N. Ochratoxins. In: Shank R.C. (Ed) Mycotoxins and N-Nitroso Compounds: Environmental Risks. Boca Raton: CRC Press,1981. p. $129-136$

[3] CANTÀFORA, A.; GOSSI, M.; MIRAGLIA, L.; BENELLI, L. Determination of ochratoxin $A$ in coffee beans using reversed-phase high performance liquid chromatography. La Rivista della Società Italiana di Scienza dell'Alimentazione, v. 12, n. 2, p.103-108, 1983.

[4] CREPPY, E.; CASTEGNARO, M.; DIRHEIMER, G. 1993. Human ochratoxicosis and its pathologies. John Libbey Eurotext, France.

[5] FURLANI, R.P.Z.; VALENTE SOARES, L.M. Avaliação de métodos para determinação de ocratoxina $A$ em cafés verdes e torrados. Revista do Instituto Adolfo Lutz, v. 58, n.1/ 2, p. $87-98,1999$.

[6] FURLANI, R.P.Z.; VALENTE SOARES, L.M. Ocratoxina A em café, Brazilian Journal of Food Technology, n. 2, v. $1 / 2$, p. $1-6,1999$.

[7] HORWITZ, W.; KAMPS, L.R.; BOYER, K.W. Quality assurance in the analysis of foods for trace constituents. Journal of the Association of Official Analytical Chemists, v. 63, p. $1344-1355,1980$.

[8] INTERNATIONAL AGENCY FOR RESEARCH ON CANCER (IARC), 1993. Ochratoxin A. IARC Monographs on the evaluation of carcinogenic risks to humans. International Agency for Research on Cancer, Geneva, pp. 489 - 521.

[9] LEONI, L.A.B.; VALENTE SOARES, L.M.; OLIVEIRA, P.L.C. Ochratoxin A in Brazilian roasted and instant coffees, Food Additives and Contaminants, v.17 n. 10, p. 867-870, 2000.

[10] LEVI, C.;TRENK, H. L.; MOHR, H. K. Study of the occurrence of ochratoxin $A$ in green coffee beans. Journal of the
Association of Official Analytical Chemists, v.57, n. 4, p. $866-871,1974$

[11] LEVI, C. Mycotoxins in coffee. Journal of the Association of Official Analytical Chemists, v. 63, n. 8, p. 1282-1285, 1980

[12] MICCO, C.; GROSSI, M.; MIRAGLIA, M.; BRERA, C. A study of the contamination by ochratoxin $A$ of green and roasted coffee beans. Food Additives and Contaminants, v. 6, n. 3, p. 333-339,1989.

[13] NAKAJIMA, M.; TSUBOUCHI, H.; MIYABE, H.; UENO,Y. Survey of aflatoxin $B_{1}$ and ochratoxin $A$ in commercial green coffee beans by high performance liquid chromatography linked with immunoafinity chromatography. Food and Agricultural Immunology, v. 9, p. 77-83, 1997.

[14] PLESTINA, R. Nephrotoxicity of ochratoxin A. Food Additives and Contaminants, v. 13, n. suplemento, p. 49-50,.

[15] SAES, M.S.M.; FARINA, E.M.M. 1999. O agribusiness do café no Brasil. Pensa/Milkbizz, São Paulo.

[16] STUDER-ROHR, I.; DIETRICH, D.R.; SCHLATTER, J.; SCHLATTER, C. The occurrence of ochratoxin A in coffee, Food and Chemical Toxicology, v. 33, n. 5, p. 341355,1995

[17] TSUBOUCHI, H.; YAMAMOTO, K.; HISADA, K.; SAKABE, $Y$. A survey of occurrence of mycotoxins and toxigenic fungi in imported green coffee beans. Proceedings of The Japanese Association of Mycotoxicology, v.19, p. 14-21,1984.

[18] TRUCKESS, M. W.; GILER, J.; YOUNG, K.; WHITE, K. D.; PAGE, S. Determination and survey of ochratoxin A in wheat, barley, and coffee. Journal of the AOAC International, v. 82, n.1, p. 85-89, 1999 .

[19] U.S. DEPARTMENT OF HEALTH AND HUMAN SERVICES, 1996. National Toxicology Program technical report on the toxicology and carcinogenesis studies of ochratoxin A in F344/N rats. National Institutes of Health, Research Triangle Park.

[20] VALENTE SOARES, L.M. Ocratoxinas e aflatoxinas em café brasileiro, Proceedings of the III International Seminar on Biotechnology in the Coffee Agroindustry, Londrina, PR, pp. 447-452, 2000.

[21] ZIMMERLI, B.; DICK, R. Study of the repeated use of commercial immunoaffinity columns, Mitteilungen aus dem Gebiete der Lebensmitteluntersuchung und Hygiene, v. 87, p. $732-742,1996$. 